\title{
33
}

\section{Relations Between Germany and China and the Rise of the Social Insurance State in China Since the Economic Reform of 1978}

\section{Tao Liu and Tong Tian}

\section{Introduction}

In the modern history of Chinese social protection, the diffusion of knowledge and model transfer have played a significant role in shaping the discourses, scripts and conceptual models in this field. In general, Chinese social policy experts avoid referring to one specific national model. Yet, there is a consensus among the Chinese social policy community that the German model of social insurance has shaped the basic design and overall architecture of modern social protection in China. So far, few studies within the social policy literature have investigated

\footnotetext{
T. Liu $(\bowtie)$

Zhejiang University, Hangzhou, China

e-mail: taoliu1975@zju.edu.cn

T. Tian

University of Bremen and Jacobs University Bremen, Bremen, Germany e-mail: tong.tian@uni-due.de 
in-depth the unique role of Germany for the development of social policy in China. ${ }^{1}$ Our study places emphasis on the impact of Germany on the semantical, conceptual and institutional development of social policy in China since the economic reform of 1978. This chapter underscores an inter-state interdependence and reveals a bilateral communicative context of social policy. The questions this chapter addresses in the following are: Why have Chinese social and political elites used the scripts and prescripts of Germany as a cognitive and institutional framework for Chinese social policy? Who are the primary actors driving knowledge transfer between these two distant countries? Who are the senders and recipients of knowledge in both countries? And finally, how do institutions transfer knowledge in the bilateral context? Thus, this chapter traces the unique role and clout of Germany in shaping social policy developments in the post-communist China.

\section{Historical Background}

The influence of Germany on social policy in China can be traced back to the epoch of the Republic of China (ROC, 1919-1949). During the emergence and early development of a fledgling industrial sector in China, exploratory studies on social protection and social policy appeared in the early twentieth century. Some scholars started to tentatively and sporadically investigate the genesis and operation of social protection in industrialised Western countries. Experiences from "early bird" countries were explored and used as theoretical and practical sources for Chinese academics. Though different social policy systems and social laws from several leading Western countries had been studied comparatively, the German system of social policy, which was renowned as a worldwide

\footnotetext{
${ }^{1}$ The major exception in the literature includes studies by Leisering and Liu, who have investigated knowledge transfer between Germany and China, as well as rationalistic policy learning among Chinese social scientists and policy-makers based on the German statutory accident insurance system (Leisering and Liu 2010; Liu and Leisering 2017; Liu 2015). However, these studies only cover one specific policy area-work accident insurance; they have merely traced the policy transformation of this field in China with a parallel analysis of inter-state policy transfer. A comprehensive analysis of the institutional impact of Germany on the overall framework of Chinese social policy has not yet been conducted.
} 
pioneer in social insurance, was underscored both by scholars and by social and labour officials within the Nanjing government. These early and historical contributions in the republican age included translated works, monographs, commentary essays, and guidelines on social policy in Germany (Li 2014; Zhu and Zhu 2014). Even the very first draft of a labour insurance regulation-the so-called Draft of the Labour Code proposed by the Labour Law Drafting Committee of the Nanjing government in 1929-was heavily influenced by German social insurance law (Zhu and Zhu 2014). At that time, the two major Chinese governments diverged in their models of social protection: while the nationalist government in China emulated the German model of social insurance, the communist government preferred the Soviet model of labour insurance. After the victory of the Communist Revolution, these two competitive models split the Chinese territory in half: while Mainland China adopted the Soviet model of labour insurance, the Taiwanese government adopted the German model of social insurance for the small Chinese island. The historical rivalry between the parties persisted throughout the Cold War (Hu 2012).

\section{Social Policy Diffusion from Germany to China in the Modern Era}

Since the end of the Maoist development path, and the adoption of economic reform and the open-door policy in 1978, China has gradually bid farewell to the Soviet model of a centrally planned economy, facilitating the development of a market economy. The Soviet economic model, as well as the Soviet style labour insurance system, has disintegrated. Amid ongoing reform, enterprises with different forms of ownership, including private enterprises, joint ventures and transnational corporations, have not only been allowed to exist but also been stimulated to thrive in the newly formed competitive domestic market. This economic transformation has made the labour insurance model borrowed from the Soviet Union outdated. Chinese officials, policy-makers and scholars from the field of social protection, as well as officials from financial and economic 
fields, were keen to import state-of-the-art knowledge from outside to create a new, modern version of social protection in China, which would be adaptable to the new market economy. Against this backdrop, the historical German influences of the early twentieth century were revived after half a century, and Chinese social and economic elites began to closely observe mainstream trends in worldwide social policy through travelling to major social insurance states and additionally through inviting officials and scholars from abroad to China to educate Chinese officials, with a special focus on the social insurance model. Germany has become one of the most relevant reference countries in this development stage.

After the bifurcation owing to different institutional preference and choices during the Cold War, social protection in two Chinese societies-Mainland China and Taiwan-started to converge. The Bismarck model of social insurance has become the systemic commonality, shaping the elementary structure of social policy in both societies. Throughout, Germany has exerted an immense impact on Chinese social policy.

\subsection{Actors and Agencies}

Within the study of diffusion, one of the most relevant questions concerns the primary actors driving the diffusion and the learning processes. In the context of the Chinese economic reform, policy-making has become rationalised and "scientised"; in other words, the role and function of scholars, scientists and intellectuals have been elevated and increasingly valued by policy-makers in China. Top leaders, technical officials, social scientists, and economists constitute the relevant issuerelated policy communities and advocacy coalitions for different fields. Some of the integrated research institutes of state ministries have played the role of think-tanks in providing reform ideas and options for government officials.

Since the economic reform, China has been actively engaged in the activities of international governmental organisations (Kent 1997), endeavouring to use the repertoire of knowledge, ideas and conceptual scripts from international actors to open a new horizon for Chinese 
policy-makers in different fields. In the 1980s, some forerunners to social protection in China had created strong ties with experts from international agencies and entities, constructing a mainstream world trend in social protection that relied on international expertise. China has modified its original institutional path, moving away from labour insurance and towards a new destination-a transformation in social insurance. Social insurance states have been scrutinised by the Chinese epistemic community more than ever before. Besides the global mega-trends observed and constructed by Chinese social and economic elites, some novel reform trends from the 1980s have been additionally identified and included into the public policy agenda, such as scripts on privatisation and individual accounts in pension reform (Zhou and Zhang 2015; Hu 2012; Hu and Manning 2010). Various international influences from different streams and different countries have overlapped in the social policy field in this post-communist transitionary context. Due to the significance of China's transformation, the social policy field has turned into a magnetic experimental field, attracting expertise from think-tanks, research institutes and foundations around the world (Liu 2018).

Due to different values and normative tendencies, various individuals and institutions have developed an uneven inclination towards different countries and models. The Ministry of Labour (MOL), later the Ministry of Human Resources and Social Security (MHRSS), ${ }^{2}$ has, for instance, consistently tended to maintain a close and intensive relationship with Germany due to its strong inclination towards the German model of social insurance. The MOL-Germany tie can be traced to the late 1980 s. Minister Luo Gan of the MOL met with representatives from the Beijing Office of the Friedrich Ebert Foundation (FES) ${ }^{3}$ on 29 November 1988, to arrange bilateral cooperation on labour issues and social security. In the 1990s, both sides deepened their cooperation and the FES has financed different pilot projects on labour protection and social protection in China, consistently playing the key role of providing expertise and social-technical knowledge to its Chinese peer colleagues.

\footnotetext{
${ }^{2}$ In 1998, the Ministry of Labour (MOL) was renamed the Ministry of Labour and Social Security (MOLSS), and in 2008, the MOLSS was renamed the MHRSS.

${ }^{3}$ In German, it is Friedrich-Ebert-Stiftung, shortened as FES.
} 
Some key figures, such as Zhou Hong from the leading think-tank in China_the Chinese Academy of Social Sciences (CASS) — and Zheng Gongcheng from Renmin University, who are widely considered the key designers and trailblazers of modern social protection in China, have built deep and enduring connections with Germany. Zhou Hong graduated from the Department of German Literature at Nanjing University in the 1960s, and she had been the director of the Institute of European Studies at the CASS for a long time, during which she created close ties and facilitated exchanges with Germany and other European countries. Zheng Gongcheng, the most eminent and influential professor at Renmin University, has also been actively engaged in the development of social policy and social protection in China, through the People's Congress, ${ }^{4}$ and has established long-term cooperation mechanisms with Germany. Through constant collaboration with the FES and with the Max Planck Institute for Social Law and Social Policy (MPISLSP) in Munich, Zheng has attempted to systematically absorb and transfer the state-of-the-art knowledge from German social policy to China. ${ }^{5}$

\subsection{Semantics and the Perception of Models}

Since the economic reform, Chinese scholars, officials and policy-makers have applied the method of "global scanning" (Liu 2018), which strives to target social protection programmes from leading OECDOrganisation for Economic Co-operation and Development-countries and Western welfare states prior to the legislation on social protection in China. Against this backdrop, the German model of social protection has been increasingly perceived and circulated within Chinese academia. The Chinese social policy community has widely conceived of the eminent position of Germany as the original pioneer of state-organised social

\footnotetext{
${ }^{4}$ Zheng Gongcheng is a member of the Tenth National People's Congress' Standing Committee and the vice president of China Social Insurance Academy.

${ }^{5}$ Zheng has regularly sent his Master's and PhD students to the MPISLSP in Munich in order to study and explore social policy knowledge. After coming back to China, these students have actively engaged in translating and transferring social policy knowledge from Germany to China. Foreign study and training abroad have become a significant method of inter-state policy learning and knowledge transference.
} 
policy, through the Bismarck model. ${ }^{6}$ Due to this inclination towards the German model, terms like "Germany", "the German model of social protection" and "the Bismarck model of social insurance" have become highfrequency terms within the discourse of the labour and social ministry (MOL, later MHRSS).

The most influential scholar-Zheng Gongcheng-believes firmly in policy learning and has profoundly influenced the Chinese epistemic community through his well-known catchphrase: "From afar, China shall learn from Germany (yuan xue deguo); from up close, China shall learn from Japan (jin xue riben).” In this case, Germany and Japan represent two typical social insurance reference models: while Germany is the original inventor of the Bismarck model, Japan embodies an East-Asian Bismarck model. According to Zheng, the chief designer of social protection, the overall architecture of Chinese social protection should be based on a primary system of social insurance, supplemented by other types of programmes, such as social assistance, social relief and different kinds of social services. Zheng's core belief in the macro-structure has crucially shaped the elementary design of Chinese social protection; the country has approached the status of a social insurance state, embracing neither the Beveridge model nor the market-steering model. Zheng's personal beliefs and his famous remarks have laid the cognitive foundation for China's learning from Germany. Even Japan represents an Asianised German model since Japan has learned from Germany, adapting the borrowed scripts and models to the local context.

Zheng's idea of learning from Germany (from afar) and from Japan (from up close) has been implemented and concretised in different social policy fields; for instance, in the reform of old-age pension insurance and in the newly piloted long-term care system. In their quest to establish a long-term care insurance system through first-step local experimentation, ${ }^{7}$

\footnotetext{
${ }^{6}$ Using the keywords "German social protection system" in the Baidu scholar search engine, one retrieves 95,200 research results. If the search period is limited to 1980-2000, there are still 23,700 relevant research results.

${ }^{7}$ Long-term care insurance was first tested in Qingdao City, Shandong Province, in 2012. In 2016, it was piloted in fifteen cities across the country. Currently, there are also voluntary pilot programmes in nearly fifty cities to provide long-term care services for disabled elderly people. Different local models have appeared, including the Qingdao model, the Nantong model, the
} 
Chinese authorities have called upon Germany and Japan as primary empirical examples for the Chinese context. For many Chinese scholars, these two countries are the two most influential in the world in terms of social insurance for handling the risks of long-term care, providing strong evidence that a social insurance model works in this distinctive field. Learning from the German and Japanese models of social insurance for long-term care has become a popular and fashionable trend within Chinese academia, and the discussions, debates and research articles on the topic have mushroomed in the past decades in China. ${ }^{8}$ The Japanese long-term care insurance system has been understood as a borrowed script from Germany that has been localised and innovated in Japan. Dr. Jin Weigang, the director of the Chinese Academy of Labour and Social Security, an integrated think-tank of the MHRSS, called upon Zheng's remark about learning from Germany (from afar) and from Japan (from up close) in the field of long-term care insurance, by explicitly referring to practices common in Germany, such as separate long-term care premiums financed by employers and employees, as well as a care-level system to establish a national standard on long-term care insurance on the occasion of an academic forum (2017) in China. ${ }^{9}$

\subsection{Interaction and Communication Channels}

Different interaction patterns and communication channels between Germany and China have facilitated the exchange and knowledge transfer between the two countries. First, ministries, institutes and research foundations from both countries have fostered institutional cooperation channels for the long term, including the strong and trustworthy institutional ties between the labour and social ministry in China and FES in Germany or between Renmin University (Zheng Gongcheng) in Beijing

\footnotetext{
Shanghai model and the Chengdu model; many of these models take Germany and Japan as a direct example for their policy design.

${ }^{8}$ Using the keywords "long-term care insurance in Germany", the Chinese scholarly search engine-Baidu Scholar-returns 50,100 research results in total.

${ }^{9}$ See the report by the China Pension Network at: http://k.sina.com.cn/article_5617251953_14 ed0767101900p453.html?from=health. Accessed on April 1, 2020.
} 
and MPISLSP in Munich. Second, since the late 1990s and particularly since the millennium, the European Union (EU) has become another relevant supranational actor promoting multiple bilateral cooperation in the field of social protection between China and other European countries. For instance, within the framework of the EU-China Social Security Reform Cooperation Project (EUCSS) and the EU-China Social Protection Reform Project (SPRP), many German experts and scholars have been invited to China to consult with Chinese officials and policymakers about social policy reform. ${ }^{10}$ Third, China and Germany have signed inter-governmental cooperation treaties for transferring the German model of social protection to China; for example, the Chinese government has strived to "import" the German model of statutory work accident insurance since 2004 (Liu 2015; Leisering and Liu 2010). The bilateral cooperation project for work accident insurance has lasted for five rounds, with the latest round signed by the two governments in 2018. ${ }^{11}$ Fourth, bilateral visits, including the invitation of German scholars, professors and officials to China and the organisation of inspection tours in Germany by Chinese officials and scholars have constituted significant interaction forms. Some Chinese ministries and universities have regularly invited eminent German experts and scholars to give lectures in China, who have, in some cases, consulted with Chinese officials about reform. For instance, professors from Renmin University, including Zheng Gongcheng, have regularly invited professors in the field of social law and jurists from Germany to Beijing in order to introduce the German social insurance laws. Chinese officials, policy-makers and scientists have regularly organised inspection and investigation tours in Germany for learning from German examples and experiences in various

\footnotetext{
${ }^{10}$ Co-funded by the EU and the Chinese government, each project lasted five years, covering domains such as pensions, unemployment insurance, administration, and management, as well as financing and budgeting. The EUCSS translated the rural pension schemes of EU member states into Chinese to help Chinese authorities draw lessons and design a rural pension model for China. The SPRP has been involved in several pilot sites in expanding universal pension coverage, supporting the Ministry of Finance in financial management related to social funds and accessing legal frameworks for social assistance.

${ }^{11}$ See "China and Germany sign the fifth letter of intent for cooperation in work injury insurance". Download under the Peoples' Net at http://world.people.com.cn/n1/2018/0728/c1002-30175341. html. Accessed on April 1, 2020.
} 
fields like pension reform, health protection, work accident insurance, unemployment insurance and social assistance. Fifth, personal trust has become an asset benefiting bilateral cooperation. As above mentioned, Zheng Gongcheng from Renmin University prefers to send his students to MPISLSP in Munich for study exchanges. Since 2016, the Faculty of Social Sciences of the University of Duisburg-Essen has become another German institute that has trained various guest $\mathrm{PhD}$ students in the field of social protection from Renmin University, Wuhan University, Huazhong Normal University and Huazhong University of Science and Technology, among others.

\section{Conclusion}

This chapter has traced the historical connectivity between China and Germany in the field of social policy, identifying a long tradition of learning from the German model of social insurance. Though the ChineseGerman connectivity in this field had been frozen in the Maoist period for about three decades, the bilateral interlinkages have been revived in the period of reform and open-door policy. Various ministries, institutes, entities and persons from both sides have woven a dense social security cooperation network, fostering domestic discourses and debates about the elementary design elements of modern social protection. Though different state departments and persons have different inclinations towards different models and different countries, ${ }^{12}$ an undeniable fact is that Germany and the Bismarck prototype of social insurance have played a significant role in setting the course for Chinese social protection. Due to

\footnotetext{
${ }^{12}$ For instance, during health insurance reform in China in 2006, different departments favoured different models: while the MOLSS favoured the German model of health insurance, the Ministry of Health was inclined towards the Beveridge model of National Health Services and the Ministry of Finance was keen to import the US market-dominated model. Another example is reflected in the personal rivalry between two eminent Zhengs: Zheng Gongcheng from Renmin University favours the German model of social insurance, while Zheng Bingwen, another prominent and influential scholar, acting as director of the Institute for American Studies of the CASS, insists on learning from the US model and promotes the discourse concerning the privatisation of social security. Zheng Gongcheng and his advocacy coalition for social insurance have been more successful in convincing policy-makers to embrace their scripts and have thus shaped the mainstream discourse on Chinese social protection.
} 
promotion by the labour and social ministry, Zheng Gongcheng from Renmin University, Zhou Hong from CASS and other actors, a basic guideline of Chinese social protection has been developed, specifying that the overall framework for Chinese social protection should be based on the German social insurance model. Notwithstanding learning from diverse sources, Germany remains the pivotal country that acts as a central model for modern social protection in China. The German-Chinese tie is a part of a panorama of interdependency and interconnectivity of social policy developments in world society and has revealed that the birth of social policy in latecomer nations is not a sporadic and isolated phenomenon, it has been rather shaped by travelling ideas and concepts through active social policy learning and emulation by epistemic communities and decision-makers.

Acknowledgements This chapter is a product of the research conducted in the Collaborative Research Center "Global Dynamics of Social Policy" at the University of Bremen. The centre is funded by the Deutsche Forschungsgemeinschaft (DFG, German Research Foundation)—project number 374666841-SFB 1342.

\section{References}

Hu, Aiqun. 2012. The Global Spread of Neoliberalism and China's Pension Reform since 1978. Journal of World History 23 (3): 609-638.

$\mathrm{Hu}$, Aiqun, and Patrick Manning. 2010. The Global Social Insurance Movement since the 1880s. Journal of Global History 5 (1): 125-148.

Kent, Ann. 1997. China, International Organizations and Regimes: The ILO as a Case Study in Organizational Learning. Pacific Affairs 70 (4): 517-532.

Leisering, Lutz, and Tao Liu. 2010. Globale Wissensdiffusion in der Sozialpolitik. Zeitschrift Für Sozialreform 56 (2): 173-206.

Li, Qiong. 2014. The Study on Theory and Practice of Social Insurance During the Period of the Republic of China. Beijing: Chinese Social Sciences Press.

Liu, Tao. 2015. Globale Wissensdiffusion in der Politik sozialer Sicherung: die Einführung einer gesetzlichen Unfallversicherung in der Volksrepublik China. Frankfurt am Main: PL Academic Research. 
- 2018. Epistemological Globalization and the Shaping of Social Policy in China. Journal of Chinese Governance 3 (4): 461-476.

Liu, Tao, and Lutz Leisering. 2017. Protecting Injured Workers: How Global Ideas of Industrial Accident Insurance Travelled to China. Journal of Chinese Governance 2 (1): 106-123.

Zhou, Hong, and Jun Zhang. 2015. Towards a Society with Social Protection for All. A Concise History of Social Security Transformation in Modern China. Beijing: Chinese Social Sciences Press.

Zhu, Huaxiong, and Jing Zhu. 2014. The Study on the Ideas of Social Insurance in the Republic of China. Wuhan: Wuhan University Press.

Open Access This chapter is licensed under the terms of the Creative Commons Attribution 4.0 International License (http://creativecommons.org/licenses/ by/4.0/), which permits use, sharing, adaptation, distribution and reproduction in any medium or format, as long as you give appropriate credit to the original author(s) and the source, provide a link to the Creative Commons licence and indicate if changes were made.

The images or other third party material in this chapter are included in the chapter's Creative Commons licence, unless indicated otherwise in a credit line to the material. If material is not included in the chapter's Creative Commons licence and your intended use is not permitted by statutory regulation or exceeds the permitted use, you will need to obtain permission directly from the copyright holder.

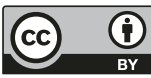

